\title{
The Influence of Nostalgic Advertising on Viral Intention and Purchase Intention
}

\author{
Ryan Dharmasaputro ${ }^{1, *}$ Adrian Achyar ${ }^{2}$ \\ ${ }^{1}$ Universitas Indonesia \\ ${ }^{2}$ Universitas Indonesia \\ *Corresponding author.Email: ryanrd92@gmail.com
}

\begin{abstract}
Nowadays, many companies attempt to combine a unique theme into their advertisement through social media platforms such as Facebook, YouTube, and Instagram. One of their purposes to attempt this strategy is to expecting become viral and increasing the purchase intention of their products from their targeted viewers. A previous study found that nostalgic content in advertise had a positive relationship with the attitude toward the ad. Thus, this present study developed a model to find the effect of the nostalgic advertisement on attitude toward the ad, attitude on the brand, purchase intention on viral intention, as well as the relationship between them. The model was tested by collecting data from respondents. The criteria for respondents were, who lived in Jakarta, between 20- 54 years old, and they did not use the advertised product. Then the next process was guiding them to watch the selected nostalgic advertisement, and the last process was filling the questionnaire form to observe the effect after watching the advertise. The findings demonstrated the nostalgic advertising had positively significant to attitude toward the ad. The study also found that there was a positive relationship between attitude and ad, attitude and brand, viral intentions and purchase intention. These findings provide insightful implications for marketers and advertisers to help them determining the content theme for their further advertising.
\end{abstract}

Keywords: Digital Marketing, Nostalgic Advertising, Attitude Towards The Ad, Purchase Intention, Viral Intention.

\section{INTRODUCTION}

\subsection{The Trends In Using Viral Video Advertising}

The Association of National Advertisers (ANA) conducted a survey which showed that almost half of people who worked as marketers were already use Viral Video advertising for their marketing purposes in 2009 [1], and this usage reached $70 \%$ in 2010 according to another survey by [2].

Based on [3], the definition to categorize a video as a viral videois still unclear, but theagencies considered a successful video is a video who gained more than one million views with $27.8 \%$ of them saying so. In other side, some peoplethink it successful if it was viewed 100,000 times, 250,000 times, or 500,000 times by $22,2 \%$.

Reference [4] concluded that not all of video advertisement deployed by marketers are watched by customers. It was found that the viewers especiallyfrom internet users may feel discomfort by intrusive advertisement when they are on the navigation and browsing activities. Although those certain ads may be produced at high cost, the marketers have to take into account the latest strategy to sustainand reach the viewers and potential customer in the most cost-effective manner [3]. Reference [5] found that in the past few years, digital marketing strategy has shifted away from an emphasis on 'paid' media, where a brand pays to advertise, to 'earned' media, where the customers themselves become the channel of delivery. In addition, [6] found the social video advertising is among the fastest-growing segments in advertising today. Reference [7] found that social video advertising views increased by $230 \%$, in which the growth is over nine times inonline search and display advertising. Reference [6]also considered these video ads are cruciallydifferent from rich-media banner ads, rather than theadvertiser paying for placement. These ads are designed to be transmitted by consumers themselves, either through consumers posting them on their social media feeds or sharing them directly with friends. This 
means that firms commission these video ads and post them on websites such as YouTube.com, expecting that consumers themselves will encourage others to watch the video, and it is evidently attractive for firms, as it implies a costless means of transmitting advertising.

\subsection{The Trends in Using Nostalgic Content as a Theme in Advertising}

Nostalgia is a powerful tool for creating an emotional connection with your audience. Research showed that almost all people tend to spend money at the time they are feeling nostalgic [8]. As the nostalgia has been a technique in marketing for just about forever. It is getting more common as the development of digital technology of mobile phones, the internet, and social media, which enables many users to gain access, modify the content, and create their own business [9].

In terms of the generation, nostalgic content can be used for middle age generation and up. Millennials seem to suffer early- onset nostalgia, as Cassandra-Mcintosh, a Senior Insights Analyst at Exponential, expected that the millennials are coming of age in the economic crisis, which having difficulty to find a job. In thiscondition, they end up to romanticize simpler timesmuch more, even those times they weren't around for [10].

Reference [9] reported in many industry sectors that the nostalgia theme has been created manysuccessful works, such as entertainment and music, FMCG, and Techno brands. It is also possible for most of consumer brands. In Indonesia, some companies have already adopted nostalgic theme to their advertises. Picture a (see Figure 1) was taken from Indo Ice cream Nusantara, which adapted a scene from a kingdom family. Another one in picture (b) is taken from Ticket.com, which adapted a scene of woman with 90's clothes and songs. (a)

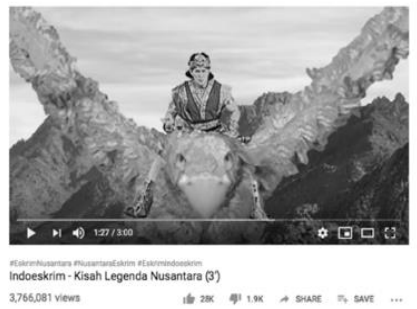

(b)

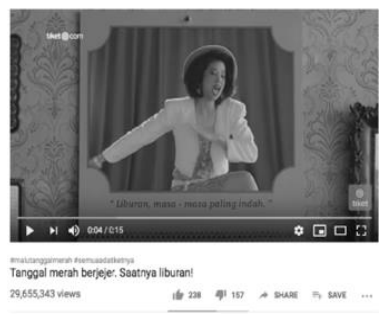

Figure 1 Example of nostalgic advertising

These advertise have reached million viewers on YouTube Channel and became hits at that time (around 2017-2019).

\subsection{The Conceptual Model}

In this research, the model used was taken from 2 research paper. The first one was taken from [11], as they confirmed a successful viral advertising campaign called the audience's attention with engaging appeals and interests through positive AD (Attitude toward the ad) and $\mathrm{AB}$ (Attitude-toward-brand), which led to the ads getting forwarded/VI (Viral Intention) as well as PI (Purchase Intention). Another research was from [12], in which they confirmed that the ADN (Ad Evoked Nostalgia) had a positive correlation with AD (attitude toward the ad) and PI (Purchase- intention).

Based on those researches, thisconceptual model is proposed (see Figure 2).

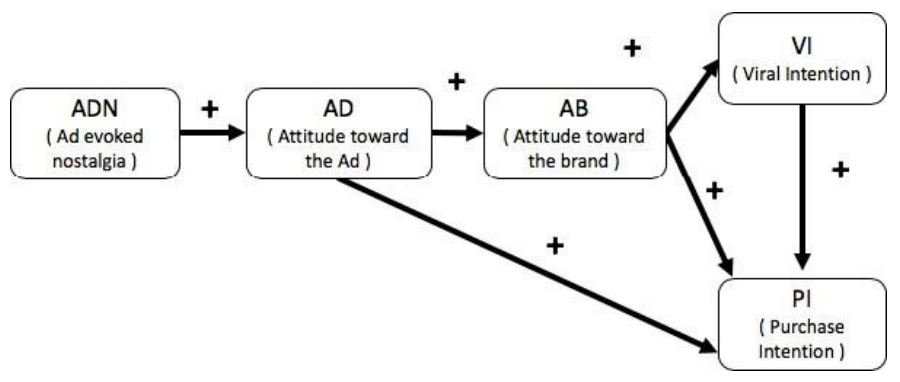

Figure 2 Conceptual Model

\subsection{Hypothesis Development}

Reference [13] found that based on previous findings, advertisements that feature tropes of personal nostalgia would produce more favorable attitudes towards the ad and brand rather than ads with no nostalgic theme. Therefore, it leads to this hypothesis:

H1: An advertisement which successfully encourage nostalgic feelings and memories (ADN) are associated with positive attitude toward the ad (AD).

H2: A positive attitude toward the ad (AD) positively affects attitude toward the brand $(\mathrm{AB})$.

Reference [14] also pointed out that a positive ad reaction led to an enhanced brand memory, familiarity, and appeal.

H 3: A favorable attitude toward the ad (AD) can positively affects the purchase-intention (PI).

Based on previous research by [1], there was a positive correlation in which the attitude toward the ad (AD) can predict the purchase-intention(PI).

H4: The attitude toward the Brand $(\mathrm{AB})$ positively affects the consumers viral-intention (VI)

H5: The attitude toward the Brand (AB) positivelyaffects the consumers purchase-intention (PI)

According to [15] research, it was found that attitude toward the brand positively influenced the behavioral variables in this model;viral intentions and purchase intentions.

H6: A positive intention of Viral (VI) affects consumers to Purchase-intention of OVO product (PI) 
In research carried out by [11], the consumers' intentions to forward an ad positively influence their intentions to buy the advertised product.

\section{METHODS}

\subsection{Object Video}

One of viral videos advertising from OVO brand was used in this study, as this company has made several nostalgic advertising videos where all of them became viral. The list of OVO advertising video can be shown at Figure 3, starting from using scene of Rhoma Irama and his girlfriend which was famous at 1980, using role of "Suzanna" as a kuntilanak which was also famous in around 1980. Based on this condition, the advertisement selected was the ones that not affected

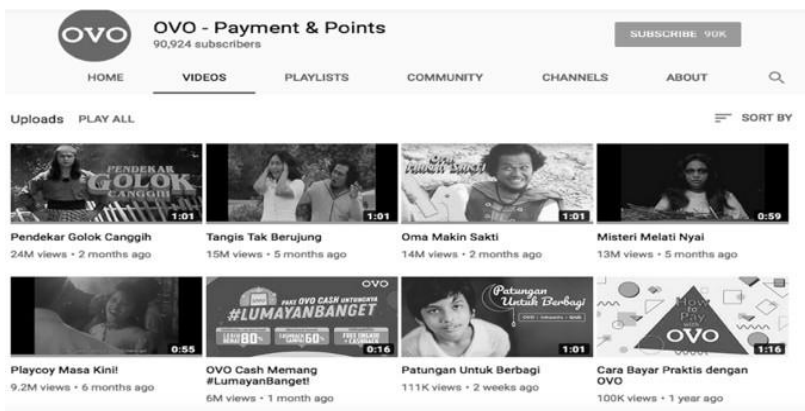

Figure 3 List of OVO advertising video [16].

\subsection{Sampling Criteria and Method}

Based on [17], in order to concentrate onpeople with particular characteristics who will betterbe able to assist with the relevant research, then the purposive sampling can be applied. As this research was conducted with several consideration such as limitation from age, and certain criteria such as:

The respondents have not used OVO mobile payment at the time they took part on the survey.

The respondents have not watched "Play CoyMasa Kini" before.

For this research, the valid respondent with total number of 160 respondentsfrom 250 respondents were obtained. For the gender, the respondents were 86 males and followed by 73 females.

\subsection{Age Criteria of Respondents}

Based on [9], nostalgic content used should be for middle age generation and up. Reference [9] stated that millennials seem to suffer early-onset nostalgia, which they have potential to have a positive respond toward to nostalgia effect. Therefore, the consideration for limitation age is from young generation (millennial) to middle agegeneration ( $\mathrm{X}$ generation) which was limited between 20-54 years old. With these criteria, 60 respondents with age $20-35$ years old and 100 respondents with $36-54$ years old have been obtained with the average age was 40 years old.

\subsection{Questionnaire research}

The 6 points Likert scale for the strictquestions in the online survey questionnaire was used. As [18] suggested to eliminate the option for respondents to answer the middle "neutral" answer. Previous research has shown that cultural backgroundhad an impact on the response style of the respondents. Respondents with Asian background tend to use and choose the middle ranges of a scale (MRS) while respondents from western background tend to use and choose the extremes (ERS). For the detail question of the questionnaire, the question from two previous researches involving 22 questions were adapted.

\subsection{Data Analyze Method}

This study aims to understand Nostalgic advertising's phenomenon that may have a positive relation to viral intentions and the intention of buying. There are links and interrelationships between them and the targeted causal model can be found. This research was therefore carried out using structural equation modeling (SEM). The research was conducted by using AMOS (Analysis of Moment Structures) application which is able to arrange the variable and analyze the inter-relationships between the variable efficiently.

\section{RESULTS AND DISCUSSION}

\subsection{Confirmatory Factor Analysis (CFA)}

From the detailed reliability test conducted by using CFA, the summary of the measurement model reliability using Composite Reliability (CR) and Average Variance Explained (AVE) is shown in Table 1 [19]. described the criteria for reliability testing as; score of $\mathrm{CR}>0.7$, and score of AVE $>0.5$. The details of the results is shown at Table 1.

Table 1. CR and AVE results

\begin{tabular}{|l|l|l|l|}
\hline Latent Constructs & CR & AVE. & Remarks \\
\hline Ad Evoked Nostalgia (ADN) & 0.976 & 0.970 & Good \\
\hline Attitude Toward the Ad (AD) & 0.864 & 0.812 & Good \\
\hline Attitude Toward the Brand (AB) & 0.880 & 0.812 & Good \\
\hline Viral Intention (VI) & 0.917 & 0.890 & Good \\
\hline Purchase Intention (PI) & 0.947 & 0.939 & Good \\
\hline
\end{tabular}

Based on the result, all of the Composite Reliability (CR) in each variable scores higher than 0.7 and the Average Variance Extended (AVE) also scores higher than 0.5 . Thus, it can be concluded that the variable of Ad Evoked Nostalgia constructs is reliable. 


\subsection{Structural Model}

Structural model was used to test the research model hypotheses by seeing whether there was a significant influence between each latent variable on the research model. Goodness of Fit (GFI) was carried out to check the model fit and then analyze therelationship between constructs. GFI was used to calculate the prediction degree of the whole model, measurement model and structural model towards correlation and covariance matrix. The intention of GFI is to compare the hypothesized model with no model at all. The detail of summary of structural Model Goodness of Fit can be seen at Table 2.

Table 2. Structural model goodness of fit results

\begin{tabular}{|l|l|l|l|}
\hline $\begin{array}{l}\text {.GoF } \\
\text { Indicator }\end{array}$ & $\begin{array}{l}\text { Fit } \\
\text { Target }\end{array}$ & $\begin{array}{l}\text { Output } \\
\text { score }\end{array}$ & remarks \\
\hline GFI & $\geq 0.80$ & 0,840 & Good Fit \\
\hline AGFI & $\geq 0.80$ & 0.800 & Good Fit \\
\hline RMR & $\leq 0.05$ & 0,048 & Good Fit \\
\hline RMSEA & $\leq 0.08$ & 0,066 & Good Fit \\
\hline NFI & $\geq 0.90$ & 0,921 & Good Fit \\
\hline RFI & $\geq 0.90$ & 0,910 & Good Fit \\
\hline IFI & $\geq 0.90$ & 0,966 & Good Fit \\
\hline TLI & $\geq 0.90$ & 0,961 & Good Fit \\
\hline CFI & $\geq 0.90$ & 0,966 & Good Fit \\
\hline
\end{tabular}

Majority of GFI score from the summary has reached thethreshold of good fit. This research then was allowed to move on to the next and final step, which was hypothesis test.

\subsection{Hypothesis Result}

The summarized of Structural Model Goodness ofFit can be shown at Table 3. For a hypothesis to be accepted, the C.R (T-Value) scoreneed to be above1.645 while pvalue must be smaller than 0.05 . From the hypothesis 6 , all of the hypotheses are accepted as they meet the required criteria.

Tabel 3. Structural model goodness of fit results

\begin{tabular}{|l|l|l|l|l|l|}
\hline $\begin{array}{l}\text { Co } \\
\text { de }\end{array}$ & $\begin{array}{l}\text { Hypoth } \\
\text { esis }\end{array}$ & $\begin{array}{l}\text { Estim } \\
\text { ate }\end{array}$ & $\begin{array}{l}\text { C.R } \\
\text { (T- } \\
\text { Valu } \\
\text { e) }\end{array}$ & P & $\begin{array}{l}\text { Rema } \\
\text { rks }\end{array}$ \\
\hline H2 & $\begin{array}{l}\text { AB } \square \\
\text { AD }\end{array}$ & 1.054 & $\begin{array}{l}11.1 \\
86\end{array}$ & $* * *$ & accept \\
\hline H3 & $\begin{array}{l}\text { PI } \square \\
\text { AD }\end{array}$ & 0.588 & $\begin{array}{l}2.00 \\
2\end{array}$ & $\begin{array}{l}0.0 \\
45\end{array}$ & accept \\
\hline H4 & $\begin{array}{l}\text { PI } \square \\
\text { AB }\end{array}$ & 0.685 & $\begin{array}{l}2.12 \\
8\end{array}$ & $\begin{array}{l}0.0 \\
33\end{array}$ & accept \\
\hline H5 & $\begin{array}{l}\text { VI } \square \\
\text { AB }\end{array}$ & 1.345 & $\begin{array}{l}12.0 \\
43\end{array}$ & $* * *$ & accept \\
\hline
\end{tabular}

\begin{tabular}{|l|l|l|l|l|l|}
\hline H6 & PI $\square$ VI & 0.239 & $\begin{array}{l}2.06 \\
5\end{array}$ & $\begin{array}{l}0.0 \\
39\end{array}$ & accept \\
\hline
\end{tabular}

Based on the score, for $\mathrm{H} 1$, itcan be considered that the advertisement has successfully encourage nostalgic feelings and memories (ADN) associated with positive attitude toward the ad (AD). For the H2, the attitude toward Ads (AD) has positively affected Attitude toward the Brand. For the H3, a favorable Attitude toward the advertisement of ads positively affects the purchaseintention (PI). For the H4,the attitude toward the Brand (AB) has positively affected the consumers viralintention (VI). For the H5, the attitude toward the Brand (AB) positively affects theconsumers purchase-intention (PI). For theH6, a positiveintention of Viral (VI) creates a positive effect on consumers to Purchase-intention of product (PI). The detail research model and its result with using AMOS application can be seen at Figure 4.

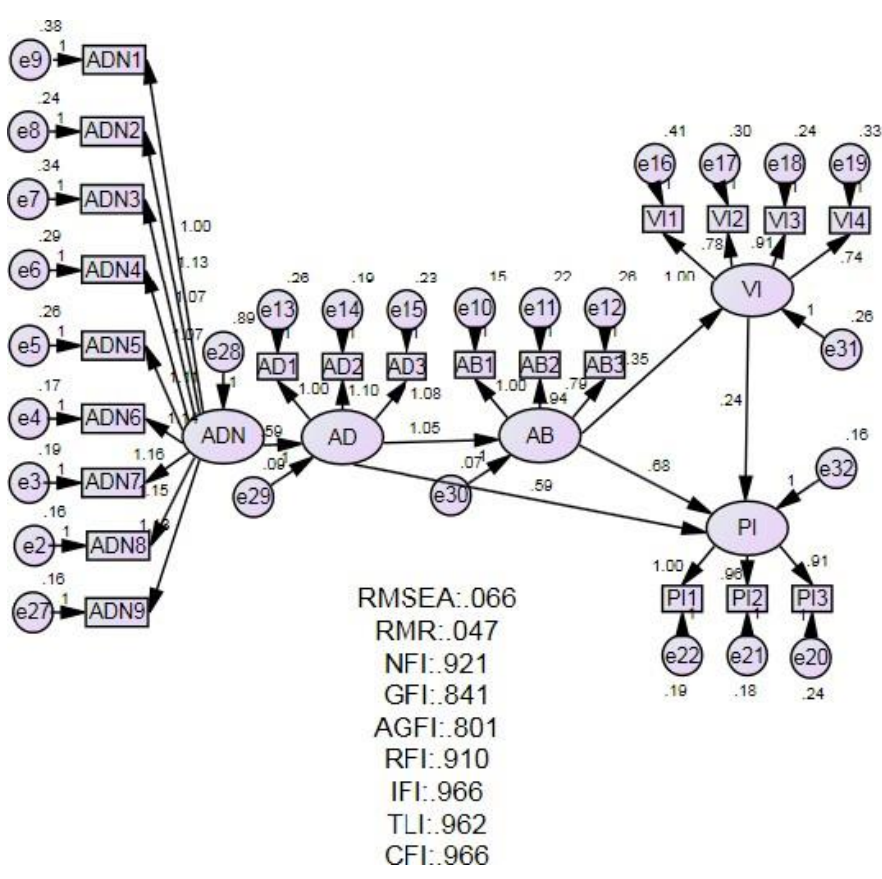

Figure 4 Research Model Result

\section{CONCLUSIONS}

\subsection{Managerial Implication}

Based on the result of research, there was a positive correlation between ad evoked nostalgia (ADN), which based on "Play Coy Masa kini" ads version, and attitudetoward-ad (AD), Attitude toward brand(AB), Purchaseintention (PI) and Viral intention (VI). Therefore, several implications to managerialare:

The personal nostalgic theme concept in "Play Coy Masa Kini" version ads was accepted in a positive way by the respondents through millennial generation to $\mathrm{X}$ generation. 
The OVO Brand can have a positive impact when the management attempt to create advertise which contains nostalgic theme.

The OVO management can attempt to create advertisements, which contain nostalgic theme in order to attract viewers and increase the potential to be viral and the viewers intention to buy the products.

\subsection{Research Limitation and Recommendation for Future Research}

This research has several limitations that ultimately may affect the results obtained. Those limitations are:

The research usage of purposive sampling method limits the research findings as they cannot be used to generalize the whole Indonesian consumer's attitude.

The research only used one nostalgic video, which cannot compare the effectiveness ofthe nostalgic video by comparing the result.

For future research, it is recommended to conduct linear regression between the age of respondents and their attitude to ad evoked nostalgia, in whichthe relationship of two variables can be acknowledge.

\section{REFERENCES}

[1] J. McCollum, "Viral Video and Social Media Marketing Up" 2009. [Online]. Available: https://pdfs.semanticscholar.org/8f87/9a6750f3ef0 29d 5bee14b1d718bb4b92df60.pdf

[2] Web Video Marketing Council, F. M. 2010. [Online].

Available: http://www.webvideomarketing.org/pdf/2010\%20 Vid

eo\%20Email\%20Marketing\%20Survey $\% 20$ and $\% 2$ 0Tr ends\%20Report.PDF

[3] Feed company. "Viral Video Marketing Survey," 2008. [Online]. Available: http://www.feedcompany.com/wpcontent/uploads/Feed_Company_Viral_Video_Ma rket ing_Survey.pdf

[4] S. Edwards, H. Li, and J.H. Lee, "Forced exposure and psychological reactance: antecedents and consequences of the perceived intrusiveness of popup ads," J. of Advertising, vol. 31, no. 3, pp. 83-95, 2002.

[5] S. Corcoran, N. Elliott, and J. Wise, "No media should stand alone: An empowered report," Defining the Roles of Owned, Earned and Paid Media in Online Marketing. Forrester Report, 2009.

[6] C.E. Tucker, "The reach and persuasiveness of viral video ads.," Marketing Science, vol. 34, no. 2, pp. 281-296, 2015.
[7] S. Olenski, "Social video advertising: The explosion of 2010," Social Media Today, 2010.

[8] D. Jannine and C. S. Lasaleta, "Nostalgia weakens the desire for money," J. of Consumer Research, 2014.

[9] Preferred media, 2017. [Online]. Available: https://preferredmedia.com.au/wpcontent/uploads/2017/11/Nostalgia-MarketingTips- For-Success.pdf

[10] T. Dua, "Why millenials are afflicted with 'earlyonset nostalgia," Digiday.com, June 15, 2015. [Online]. Available: https://digiday.com/marketing/early-onsetnostalgia- surge-cola-mad-libs-renaissance/

[11] P.K.M. Petrescu, Viral Advertising: A Field Experiment on Viral-intentions and Purchaseintentions. Florida, USA: Taylor \& Francis Group, LLC, 2015.

[12] J. Ilyoung, W.J. Jong, D. A. Naa, and J. Morris, The influence of life satisfaction on nostalgic advertising and attitude toward a brand. Florida, USA: Taylor \& Francis Group, LLC, 2015.

[13] D.D. Muehling and V.J. Pascal, "An involvement explanation for nostalgia advertising effects," J. of Promotion Management, vol. 18, no. 1, pp. 100118.

[14] W. Baker, J.W. Hutchinson, D. Moore, and P. Nedungadi, "Brand Familiarity and Advertising: Effects on the Evoked Set and Brand Preference," Advances in Consumer Research, vol. 13, no. 1, pp. 637-642.

[15] G. Biehal, D. Stephens, and E. Curlo, "Attitude toward the ad and brand choice," J. of Advertising, 1992.

[16] Payment \& Points, OVO, 2017. [Online]. Available:

fwehttps://www.youtube.com/channel/UCtu3stb17 we L-6EBLaNZCnw

[17] E. Ilker and S. Abubakar, "Comparison of convenience sampling and purposive sampling," American J. of Theoretical and Applied Statistics, pp. 1-4, 2016.

[18] A.W. Harzing, K. Köster, and S. Zhao, "Response style differences in cross-national research,' Management International Review, pp. $341-363$, 2012.

[19] N.K. Malhotra, Marketing Research an Applied Orientation. London: Pearson, 2010. 